\title{
Economic Rationale, Trade Impact and Extent of Antidumping - A Case Study of Pakistan
}

\author{
Ahmed Nawaz Hakro* and Syed Hasanat Shah
}

\begin{abstract}
This paper has analyzed the economic and political justification, trade impact and extent of antidumping measures initiated by Pakistan. Screening models for anti-predatory behaviour, Herfindabl-Hireshmann Index (HHI) for concentration and descriptive statistical measures are used to test the antidumping (AD) behaviour. The results are consistent with the earlier literature that $A D$ duties have both a trade reduction and diversion effect. It is evident from the results in half of the cases studied that an economic rationale has been followed in the application of $A D$ duties in Pakistan. Although the number of $A D$ cases is limited, Pakistan has emerged as one of the intensive users of $A D$, relative to its total import share. It is also evident from the fact that intensive use of $A D$ reduces trade and increases trade barriers, similarly, trade diversion reduces the chances of trade reduction. The key message emerging from this research is that trade diversion persists and in some cases trade diversion is substantial and it offsets the effect of $A D$ measures on named countries to the benefit of non-named countries.
\end{abstract}

\footnotetext{
* Visiting Scholar, Department of Economics, Glasgow University, Glasgow, UK. Email: hakro@qau.edu.pk

** Graduate Student, Department of Economics, QAU Islamabad, Pakistan. E.mail: hasnaatsyed@yahoo.com
} 


\section{Introduction}

Large-scale recourse $^{18}$ to antidumping ${ }^{19}(\mathrm{AD})$ has raised fears among researchers, analysts and specialists of its use as a protectionist measure, e.g. Viner (1923), Barcelo (1971), Trebilock and Quinn (1979), Leclerc (1999). While some have raised questions about the ambiguities regarding AD's effects on trade, others have questioned the economic rationale behind such actions. Many scholars suggest that $\mathrm{AD}$ measures are inefficient and do not conform to the economic explanation of protection, e.g. Tharakan and Waelbroeck (1994), Tharakan (1995). On the other hand, some economists also argue that charging two or more prices for a similar product in two or more markets separated by tariffs, transport costs and technical standards is economically rational in many situations, e.g. Viner (1923), Willig (1998), Messerlin and Tharakan (1999), or that producers keep prices low strategically when they introduce a product in a new market to create demand for it (Boltuck, 1991). In addition, if a firm produces what is called 'learning by doing' products (Deardorff, 1993) then the firm, by charging lower prices in foreign markets, will gain in experience as well as increase their sales revenue.

The most frequently offered economic justification for antidumping laws is that these laws protect competition and consumers. For most scholars, the consumer welfare standard is the main measure of economic efficiency, which suggests that antidumping laws are created to prevent predatory pricing. Conversely, Stiglitz (1997) considered that there is essentially no connection between national welfare considerations and $\mathrm{AD}$ protection; it is simply a strategy to protect the domestic industry. Therefore, strategic trade policy is the other protection-based justification for the imposition of $\mathrm{AD}$ duties, as a measure against 'strategic dumping' (Willig, 1998). Strategic trade policy is the investment by the dumping country or firm to occupy a major market share to generate externalities,

\footnotetext{
18 The number of antidumping petitions increased very rapidly into the hundreds after the implementation of Article VI of the General Agreement on Tariffs and Trade 1994 which entered into force on January 1995. From 1980-85 four user, US, EU, Australia, Canada, accounted for more than $99 \%$ of all filings (Finger, 1993). Prior to 1988 none of the developing countries filed any cases. Total AD initiations by all the AD users in 1995 were 157, then increased to 364 in 2001 and reached 191 in 2005. This surge of AD activity has been noticed on face value of $\mathrm{AD}$ petition numbers without taking into consideration the economic rationale.

${ }^{19}$ Broadly speaking a product is said to have been dumped if it is introduced into the commerce of another country at less than the normal value of the product and it causes/threaten material injury to an established industry of the importing country (Aggarwal, 2002). Antidumping duties are imposed against the dumped products by the host country.
} 
e.g. Katrak (1977), Svedberg (1979). In theory, a role for strategic trade policy emerges in two situations: imperfect competition and economies of scale in production.

For the legal imposition of $\mathrm{AD}$ duties, three basic conditions need to be satisfied: first, the existence of a dumping margin must be established; second, the material injury to concerned domestic industries must be shown; and third, the causal relationship between dumped imports and material injury to domestic industries must be demonstrated (Lee-Mah, 2003). Difficulties arise when firms exercise market power. In such instances, government intervention can be justified. The problem arises because the instruments that are usually available to a government to discipline a domestic firm, such as anti-trust regulation, are not effective in the case of foreign-based enterprises ${ }^{20}$. In the absence of antitrust instruments, the government resorts to other alternatives. A resurrection of trade barriers is a possibility. Another option is the use of antidumping policies, which allow governments to impose duties whenever goods are sold in export markets at less than their 'fair value'. These policies, in essence, prevent the country's (firms) attempts at price discrimination between markets, which could lead to material injury of the domestic industry. Given the international dimension, the advantage of $\mathrm{AD}$ is that it does not require any supranational powers. The disadvantage of $\mathrm{AD}$ policies is that these policies do not fully address the problem of market power and indeed often induce more distortions in the market than they resolve, and are often captured by special interest groups. It is generally believed that the negative impact of $\mathrm{AD}$ outweigh the positive ones. Therefore, a major part of this paper is an investigation of the economic motives behind $\mathrm{AD}$.

It is possible that dominant domestic producers in concentrated industries use $\mathrm{AD}$ laws to protect themselves from foreign competition. This 'small firm' argument is supported by researchers, yet they are unable to establish that concentrated industries are more likely to gain favourable decisions, e.g. Finger et al. (1982). Oligopolists may use their lobbying power effectively to obtain protection from import competition, see e.g. Tharakan (1994), Tharakan and Waelbroeck (1994) and Hutton and Trebilcock (1990). Similarly, politics play a significant role in the widespread use of AD [Hansen and Prusa, (1996, 1997) Agarwal, (2002)], while another

\footnotetext{
${ }^{20}$ The exporting country could, of course, also use anti-trust policies to force its firms to behave more competitively in foreign markets, but it frequently is not in the interest of the nation to do so (Levinsohn, 1996).
} 
study (Finger et al. 1982) found no evidence of political influence on the widespread use of $\mathrm{AD}$.

One way to make a sense of $\mathrm{AD}$ use is to observe the pattern of its use among the countries. The worldwide explosion in the use of AD duties has been widely documented e.g. Blonigen and Prusa, (2003), Miranda, Torres, and Ruiz (1998) and Messerlin (1989). If, for no other reason, the widespread use of $\mathrm{AD}$ makes it an important research topic. One factor behind the rise of antidumping protection could be that countries are engaged in retaliatory mini-trade wars (Prusa and Skeath, 2002). Similarly, cumulation (which is defined as the practice of aggregating over the exports of several countries) has a super additive effect on the AD surge, see e.g. Tharakan, Greenway, and Tharakan (1998), while increasingly the weak standard of $\mathrm{AD}$ is another factor in $\mathrm{AD}$ proliferation (Hansen and Prusa, 1995), Miranda, Torres, and Ruiz (1998) Finger, Ng, and Wangchuk (2000). Such indiscriminate use of AD will negatively affect the expected positive outcomes of liberalized trade under the WTO regime. AD measures can be justified as a response to unfair import competition. But the recent surge in $\mathrm{AD}$ investigations can clearly not be explained by an increase in unfair trading practices alone. One of the major concerns for international firms is also the growing importance of the so-called 'technical track' of trade policy (Finger, 1993). It increasingly appears that many companies no longer seek competitive victory in the fields of commerce and trade but in the halls of justice and regulators.

According to the review of the empirical work on the impact of $\mathrm{AD}$ measures (Blonigen and Prusa, 2003), most of the empirical studies conclude for USA and EU data, that it significantly reduces imports from namedcountries, see e.g. Staiger and Wolak (1994), Prusa (1997), Messerlin (1989), and Brenton (2001). As a result, $\mathrm{AD}$ sometimes causes trade diversion rather than its reduction, as its effects depend on a number of factors such as: concentration of industries, extent of injury and margin of dumping. For example, in case of severe injury, antidumping duties would be higher, which might be a potential threat to exports of dumping firms, but in the case of minor injury, the $\mathrm{AD}$ duty would be small and would likely not pose any threat to other firms/countries that would wish to increase their exports.

Consequently, the objectives of this study are: i) to find out the economic rationale behind the use of $\mathrm{AD}$, and whether it disciplines the behaviour of imperfectly competitive firms in international markets or not. 
ii) To examine the use of $\mathrm{AD}$ by Pakistan ${ }^{21}$. iii) To check the $\mathrm{AD}$ measures/effects on trade reduction/diversion patterns.

The rest of the paper is organized as follows: Section II describes the methodology, hypothesis, variables and data, Section III-discusses the results, and finally Section IV concludes with policy recommendations.

\section{Methodology, Hypothesis Variables and Data}

The methodology used in this paper is based mostly on statistical and descriptive techniques, but we have also used models for antipredatory behaviour, such as the screening method, which has the advantage of relying exclusively on published information. The presence of predatory behaviour will provide an economic justification for antidumping. Five screen tests are conducted; the first screen test is based on the foreign firm having a forecasted market share of 40 percent in Pakistan. If the market share is more than 40 percent, it would indicate predatory behaviour of a foreign firm. The second screen test consists of eliminating the cases where antidumping duties are not imposed. The third screen test takes into account the number of countries involved in a given case. If the number of countries is more than four, then the chance of collusion diminishes. The fourth screen test aims at taking into account another aspect of the cost of colluding: the numbers of firms involved in a given case. If the number of firms involved in a case is more than eight then the chances of collusion are low. The fifth screen test considers foreign firm market shares and the number of competitors of the domestic industry. Low foreign firm share and multiple competitors does not suggest the existence of a non-competitive market favourable to predatory behaviour. These screen tests are widely used in the 'EC contingent protection of antidumping instruments ${ }^{22}$, see e.g. also Bourgeioes and Messerline (1998).

\footnotetext{
${ }^{21}$ In Pakistan, antidumping investigations are carried out by the government agencies (National Tariff Commission working under the Ministry of Commerce). An investigation is normally initiated by means of an application filed by or on behalf of a domestic industry, which must include evidence of dumping, injury and a causal connection between the two. The investigation determines whether or not there has been dumping, which exists where the export price is below normal value. Normal value may be based on prices of sales to third countries, or constructed value, which is cost of production plus profit, where home market sales is not available or cannot be used. The investigation also determines whether the dumped imports have caused or threaten to cause material injury to a domestic industry producing the like product.

${ }^{22}$ www.iie.com/publications/chapters_preview/102/appbiie2733.pdf, see pg. 355.
} 
We analyzed the composition of foreign firms using the Herfindah1Hireshmann Index (HHI). For the 'Retaliation' and 'Strategic Industry ${ }^{23}$ arguments, we used descriptive analyses of antidumping cases, the number of producers, the number of petitioners and their market shares, taken as variables for Pakistan and against Pakistan. Case by case analysis is presented in Appendix-A.

The Herfindhal-Hirschman concentration index ( $\mathrm{HHI}$ or $\mathrm{H})$ is used to measure the concentration in import. It is given by:

$$
\mathrm{H}=\sum \mathrm{s}_{\mathrm{i}}^{2}
$$

where $\quad s_{i}=m_{i} / M$

where $m_{i}$ is the imports or production of firm $i$ and $M$ is total imports or production (i.e. $M=\sum_{i} m_{i}$ ). Thus, $s_{i}$ is the share of import or production of firm i on total import production.

\section{Spread of Antidumping}

The weighted Antidumping Intensity Index (ADI) is used, which measures the intensity of $\mathrm{AD}$ for a country that is accused of dumping relative to its export or user of antidumping relative to its import performance. The ADI for a country (or region) $\mathrm{i}$ can be calculated as follows:

$$
\left.A D I_{i}=\mathrm{I}_{\mathrm{i}}^{\mathrm{t}, \mathrm{t}+\mathrm{n}} / \mathrm{I}_{\mathrm{w}}^{\mathrm{t}, \mathrm{t}+\mathrm{n}}\right) /\left(\mathrm{M}_{\mathrm{i}}^{\mathrm{t}, \mathrm{t}+\mathrm{n}} / \mathrm{M}_{\mathrm{w}}^{, \mathrm{t}, \mathrm{t}+\mathrm{n}}\right)
$$

Where $I_{i}^{t, t+n}$ is the number of $A D$ investigations/measures against country $i$ (or product, region) between years $\mathrm{t}$ and $\mathrm{t}+\mathrm{n} ; \mathrm{I}_{\mathrm{w}}{ }^{\mathrm{t}+\mathrm{t}}$ is the total number of investigations/measures conducted globally in years $t$ and $t+n ; M_{i}^{t, t+n}$ is the value of exports/imports of a country $i$ between years $t$ and $t+n$; and $M_{w}{ }_{w}^{t, t+n}$ stands for world export/import.

If the index value is above unity, then the country or region is intensively affected by (or has used) $\mathrm{AD}$ actions relative to its share in global export (import) markets. $\mathrm{AD}$ action is considered proportional if the index is at unity, while less than unity means that the country is lightly affected by $\mathrm{AD}$. The trade-weighted ADI index can be applied to the initiation of investigations as well as to definitive measures.

\footnotetext{
${ }^{23}$ Dominant domestic producer and oligopolists may use their lobbying power effectively to obtain protection from import competition.
} 


\section{Statistical Test for Trade Impact}

Mean-differences tests on imports before and after $\mathrm{AD}$ is used to calculate the trade impact of $\mathrm{AD}$.

\section{Data}

A total of six $\mathrm{AD}$ cases, which were successfully concluded in Pakistan before December 2005, are used for analysis. This is a small sample, but it varies in terms of the representation of different sectors. Three out of six cases are from the chemical industry, two are from the rubber and plastic industry and one case is from the base metal industry. The data regarding the number of firms and countries which were investigated, the dumping margin, antidumping duties and the negative or affirmative decisions in the antidumping cases were collected from the nonconfidential reports published by the National Tariff Commission, Government of Pakistan.

Export and import data of some selected countries were used to measure the intensity. Export data at f.o.b and import data at c.i.f was gathered from the International Financial Statistics, IMF. PRAL (Pakistan Revenue Automation Limited) provides data on the import of investigated products into Pakistan.

\section{Hypotheses}

The following hypotheses are tested.

1. Antidumping measures in Pakistan are anti-predatory in nature.

2. 'Retaliation' and 'Strategic industry' arguments are the real reasons for imposing $\mathrm{AD}$.

3. Concentrated domestic industries are more likely to gain favorable antidumping decisions.

4. Import concentration can be linked to material injury and antidumping duties reduces import concentration.

5. Pakistan is more intensive on average in terms of antidumping measures.

6. The sample mean of imports after $\mathrm{AD}$ duty $\leq$ sample mean of import before $\mathrm{AD}$ duty. 
7. Trade diverts from the named countries to non-named countries.

\section{Results}

Three rationales for the economic justification of $\mathrm{AD}$, i.e. 'Antipredation', 'Political Economy' and 'Strategic Trade Industry' are tested in this analysis. We quantify the use of Pakistan's $\mathrm{AD}$ intensity as a parameter of spread. The study also considers whether $\mathrm{AD}$ use leads to overall import reduction and sometimes import diversion.

\section{Antidumping and Predation}

Five simple screening tests are used to tackle the question of whether antidumping cases are anti-predation cases or not. The results in Table-I suggest that the $\mathrm{AD}$ cases in Pakistan do not address predation issues at least in three cases. Passing of each test is represented by 1 and in case of failure by 0 . For the anti-predatory nature it is necessary for the antidumping case to pass all the five tests: That an antidumping case results into a positive outcome, forecasted market share is above 40 percent, numbers of countries are below four and number of firms below eight. However, it is not certain whether the import market is equally shared by the firms and countries. For this, four years combined index of HHI is used to conduct the fifth test. Minimum $\mathrm{HHI}$ is based on the assumption that the aggregate market share for the foreign firm is split equally among them. Maximum HHI is based on the assumption that all foreign firms except one have the market share close to zero. HHI value for a case above or equal to the threshold level of 0.18 is indicated in the Table by 1 , which shows severe concentration. Three out of four cases shows HHI value more than 0.18 , while $\mathrm{HHI}$ is less than the threshold level in one case, that is 'Tinplate' imported from South Africa. Therefore, this case has been dropped from the anti-predation test. Only three cases out of six successfully completed the screen tests, which show that almost half of $\mathrm{AD}$ cases in Pakistan cannot be proven to address competition. The result shown in Table-1 is similar to what has been found for US AD cases (Shin 1997). The anti-predation test process demonstrates the acquisition of a large market share by the importer; the atleast capacity exists to exercise and keep market power, once a large market share is obtained. 
Table-I: Results of Screening Test

\begin{tabular}{|c|c|c|c|c|c|c|c|}
\hline HS code & $\begin{array}{l}\text { Product } \\
\text { Name }\end{array}$ & Industry & Test.1* & T. $2^{* *}$ & T. $3^{* * * *}$ & T. $4^{* * * * *}$ & T. $5^{* * * * * * * *}$ \\
\hline 7210.1200 & Tinplate & $\begin{array}{l}\text { Base } \\
\text { Metal }\end{array}$ & 1 & 1 & 1 & 1 & 0 (drop) \\
\hline $\begin{array}{l}2905.4400 \& \\
3824.6000\end{array}$ & $\begin{array}{l}\text { Sorbitol } 70 \% \\
\text { solution }\end{array}$ & Chemical & 1 & 1 & 1 & 1 & 1 \\
\hline 2915.2100 & $\begin{array}{l}\text { Glacial Acetic } \\
\text { Acid }\end{array}$ & Chemical & 1 & 1 & 1 & 1 & 1 \\
\hline 5501.3000 & $\begin{array}{l}\text { Acrylic Tow } \\
\text { (AT) }\end{array}$ & $\begin{array}{l}\text { Rubber } \\
\text { plastic }\end{array}$ & 1 & 1 & 1 & 1 & 1 \\
\hline 3904.1000 & $\begin{array}{l}\text { PVC Resin } \\
\text { (PVCR) }\end{array}$ & $\begin{array}{l}\text { Rubber } \\
\text { plastic }\end{array}$ & 1 & 0 (drop) & - & - & - \\
\hline 3909.1010 & UFMC & Chemical & 1 & 0 (drop) & - & - & - \\
\hline
\end{tabular}

*Passing Screen No.1 $\geq 40$ percent market share $=1$, otherwise $=0$ (Affirmative or negative duty).

** The cases in which antidumping duties are imposed $=1$, otherwise $=0$.

*** Less than four countries investigated $=1$, otherwise $=0$.

**** Less than 8 firms investigated $=1$, otherwise $=0$.

$* * * * * \mathrm{HHI}(\mathrm{imp}) \geq 0.1818$ as high concentration $=1$, otherwise $=0$

\section{Antidumping and Political Economy}

Table-2 demonstrates that five out of six petitioners are the sole producers in the domestic market while the sixth petitioner holds 83 percent of domestic production. Clearly, the petitioners are the dominant producers in their industry. 
Table-2: Market Share of the Petitioner

\begin{tabular}{lccc}
\hline \multicolumn{1}{c}{ Product Name } & $\begin{array}{c}\text { Number of } \\
\text { domestic firms }\end{array}$ & $\begin{array}{c}\text { Number of } \\
\text { petitioners }\end{array}$ & $\begin{array}{c}\text { Share of petitioner in } \\
\text { domestic production }\end{array}$ \\
\hline Tinplate & 1 & 1 & $100 \%$ \\
Sorbitol 70\% solution & 1 & 1 & $100 \%$ \\
Glacial Acetic Acid & 1 & 1 & $100 \%$ \\
Acrylic Tow (AT) & 1 & 1 & $100 \%$ \\
PVC Resin (PVCR) & 1 & 1 & $100 \%$ \\
(UFMC) & 3 & 1 & $83 \%$ \\
\hline
\end{tabular}

The importer can cause material injury, if the import is highly concentrated. The assertion that the dominancy of only a few countries on the import market provides them the ability to use imports as a political weapon and dump imports. We can consider it as a case of sporadic dumping which occurs at certain points in the business cycle. Therefore, the first question that arises is: Was the increase in international trade evenly distributed across countries or has it been concentrated among a few countries? The second question is: In case of trade diversion does import concentration reduce or remain the same among the importers?

In order to evaluate the level of concentration in total imports, we employed the HHI index. The results are reported in Table-3.

Table-3: Results of HHI

\begin{tabular}{lrrrrrrrr}
\hline \multicolumn{1}{c}{ HHI } \\
\hline Product/Year & $\mathbf{1 9 9 8}$ & $\mathbf{1 9 9 9}$ & $\mathbf{2 0 0 0}$ & $\mathbf{2 0 0 1}$ & $\mathbf{2 0 0 2}$ & $\mathbf{2 0 0 3}$ & $\mathbf{2 0 0 4}$ & $\mathbf{2 0 0 5}$ \\
\hline Tinplate & 0.12 & 0.16 & 0.14 & 0.15 & $0.13^{*}$ & 0.20 & 0.14 & 0.13 \\
Sorbito1 & 0.62 & 0.62 & 0.69 & 0.48 & 0.45 & $0.31^{*}$ & 0.29 & 0.27 \\
GAA & 0.84 & 0.80 & 0.76 & 0.74 & 0.71 & 0.48 & $0.40^{*}$ & 0.85 \\
Acrylic Tow & 0 & 0.32 & 0 & 0.15 & 0.18 & 0.16 & $0.20^{*}$ & 0.15 \\
PVC Resin & 0 & 0 & 0.26 & 0.28 & 0.28 & 0.20 & 0.27 & $0.32^{*}$ \\
UFMC & 0.69 & 0.82 & 0.90 & 0.80 & 0.90 & 0.84 & 0.90 & $0.92^{*}$ \\
\hline
\end{tabular}

*shows antidumping duty imposition year. 
The threshold level of HHI is 0.18 . Table- 3 shows that the value of import concentration is high, ranging from 0.12 to 0.92 . This shows severe concentration. The import concentration ratio further increases in some cases after the imposition of an antidumping duty on the alleged producer, as obvious in the case of GAA (Galcial Acetic Acid imported from Taiwan) where import concentration jumped in the year of antidumping imposition, from 0.40 to 0.85 in the next year. This is because after the imposition of the antidumping duty, imports from Taiwan were reduced to zero, while Malaysia, another major exporter of GAA into Pakistan captured the entire import market of Taiwan and increased its exports to Pakistan by 50 percent just after the imposition of the duty.

\section{Strategic Industry and Antidumping}

Retaliation is a strategic reaction; therefore, it is necessary to check whether antidumping cases in Pakistan are of a retaliatory nature or not. The result shows that Pakistan's $\mathrm{AD}$ cases are neither firm specific nor country specific. Rather, these are of 'strategic industry specific' nature. The results in Table 4 show that most of the measures taken against Pakistan are in the textile sector. It seems quite logical because the textile sector contributes 68 percent to total Pakistani exports.

Table-4: Category Wise Division of AD Measures

\begin{tabular}{|c|c|c|c|c|c|}
\hline \multicolumn{6}{|c|}{ Retaliation / strategic Industry } \\
\hline \multicolumn{3}{|c|}{ AD measure taken against Pakistan } & \multicolumn{3}{|c|}{ AD measure taken by Pakistan } \\
\hline Country & Category & Number & Country & Category & Number \\
\hline Egypt & $\begin{array}{l}\text { Textile and } \\
\text { Textile Artic }\end{array}$ & 1 & South Africa & Base Metal & 1 \\
\hline $\mathrm{EU}$ & Textile & 2 & $\begin{array}{l}\text { Indonesia/ } \\
\text { France }\end{array}$ & Chemical & 1 \\
\hline Japan & Textile & 1 & Taiwan & Chemical & 1 \\
\hline Peru & $\begin{array}{l}\text { Chemical and } \\
\text { allied industries }\end{array}$ & 1 & Uzbekistan & $\begin{array}{l}\text { Rubber / } \\
\text { Plastic }\end{array}$ & 1 \\
\hline \multirow[t]{2}{*}{ South Africa } & Textile & 1 & Iran/Korea & $\begin{array}{l}\text { Rubber/ } \\
\text { Plastic }\end{array}$ & 1 \\
\hline & & & China & Chemical & 1 \\
\hline Total & & 6 & & & 6 \\
\hline
\end{tabular}


There is a clear difference in the origin of countries against whom measures are taken and those who take measures against Pakistan. Table4 shows that 50 percent of $\mathrm{AD}$ cases in Pakistan are in the chemical industry, which is a strategic industry ${ }^{24}$ and generates positive externalities.

\section{Antidumping Spread ${ }^{25}$}

$\mathrm{AD}$ intensity index measures how intensive Pakistan is in terms of $\mathrm{AD}$ initiation and measures, relative to its import and export share in world trade. AD intensity is estimated for other countries representing different regions and diverse economies to show how intensive Pakistan is in terms of $\mathrm{AD}$ measures and initiation relative to other countries. Table 5 shows that Pakistan's $\mathrm{AD}$ initiation is 2.62 times more intensive as compared to its share of imports in the world. No doubt, the number of cases initiated by Pakistan is far less than the number of cases initiated by the USA. But the USA is a less intensive user of $\mathrm{AD}$, with an index of 0.84 , as compared to its relative share in world imports. Table 5 shows that the most intensive users of $\mathrm{AD}$ in the world are Argentina and India.

$\mathrm{AD}$ intensity can be considered as a proxy for the spread of $\mathrm{AD}$. The intensity index in Pakistan ranges from 2.6 to 3.3. This shows that $\mathrm{AD}$ spread in Pakistan is gaining momentum. If we consider the $\mathrm{AD}$ index of the USA as a standard parameter and compare other countries' intensity value with the USA, we arrive at the conclusion that Pakistan is almost four times as intensive a user of $\mathrm{AD}$ measures as compared to the USA.

\footnotetext{
${ }^{24}$ The sector which generates positive externalities, see e.g. Tyson (1992).

${ }^{25}$ Spread is wide and intensive use of AD.
} 
Table-5:.Intensity Measure of AD

\begin{tabular}{|c|c|c|c|c|c|c|c|c|}
\hline \multicolumn{9}{|c|}{ Intensity Measure 2000-2005 } \\
\hline \multirow[t]{2}{*}{ Country } & \multicolumn{2}{|c|}{$\begin{array}{l}\text { AD Initiation } \\
\text { Intensity }\end{array}$} & \multicolumn{2}{|c|}{$\begin{array}{c}\text { AD Measure's } \\
\text { Intensity }\end{array}$} & \multicolumn{2}{|c|}{$\begin{array}{c}\text { AD Initiation } \\
\text { Intensity }\end{array}$} & \multicolumn{2}{|c|}{$\begin{array}{c}\text { AD Measure's } \\
\text { Intensity }\end{array}$} \\
\hline & $\begin{array}{c}\text { Relative } \\
\text { to } \\
\text { import }\end{array}$ & $\begin{array}{c}\text { Relative } \\
\text { to USA } \\
\text { /times }\end{array}$ & $\begin{array}{c}\text { Relative } \\
\text { to } \\
\text { import }\end{array}$ & $\begin{array}{c}\text { Relative } \\
\text { to USA } \\
\text { /times }\end{array}$ & $\begin{array}{c}\text { Relative } \\
\text { to } \\
\text { Export }\end{array}$ & $\begin{array}{c}\text { Relative } \\
\text { to USA } \\
\text { /times }\end{array}$ & $\begin{array}{c}\text { Relative } \\
\text { to } \\
\text { Export }\end{array}$ & $\begin{array}{c}\text { Relative } \\
\text { to USA } \\
\text { /times }\end{array}$ \\
\hline Argentina & 26.82 & 31 & 29 & 41 & 2.8 & 5.3 & 1.4 & 3.2 \\
\hline Australia & 4.29 & 5 & 3.3 & 4.7 & 0.67 & 1.2 & 0.50 & 1 \\
\hline Chili & 1.24 & 1.5 & 0 & 0 & 3 & 6 & 3 & 6.6 \\
\hline China & 1.40 & 1.6 & 1.15 & 1.6 & 3 & 6 & 3.3 & 7.3 \\
\hline Egypt & 7.64 & 9 & 7 & 10 & 3.3 & 6.3 & 0 & 0 \\
\hline $\mathrm{EU}$ & 0.75 & 0.86 & 0.67 & 0.95 & 0.12 & 0.23 & 0.12 & 0.26 \\
\hline India & 20.15 & 23.5 & 26 & 37 & 6 & 11 & 4.6 & 10 \\
\hline Pakistan & 2.62 & 3 & 3.3 & 4.5 & 2.6 & 5.2 & 2.5 & 5.6 \\
\hline S. Africa & 8.41 & 10 & 7.4 & 10 & 4 & 7.7 & 4.3 & 9.5 \\
\hline Thailand & 2.00 & 2.4 & 2.1 & 3 & 3.8 & 7.2 & 3.8 & 8.5 \\
\hline USA & 0.84 & 1 & 0.70 & 1 & 0.52 & 1 & 0.4 & 1 \\
\hline
\end{tabular}

Pakistan's $\mathrm{AD}$ initiation intensity and measure intensity taken are 2.62 and 3.3 respectively. The value of 2.6 means that Pakistan is almost a two and half time more severe user of antidumping as compared to its import share in world trade. The $\mathrm{AD}$ intensity index of being investigated for Pakistan is 2.6 and 2.5 in terms of initiation and measures. This shows that Pakistan has not only emerged as an intensive user of $\mathrm{AD}$ investigation but it is one of the most severe victims of $\mathrm{AD}$ investigation relative to its share of imports and exports in world trade. For this purpose we estimated symmetry ratios.

Table- 6 shows the symmetry ratios of $\mathrm{AD}$ measures and initiation. We divided the $\mathrm{AD}$ intensity index of investigation by the $\mathrm{AD}$ intensity index of being investigated which provides a value of the symmetry ratio. The symmetry ratio of Pakistan (1.2) shows that $\mathrm{AD}$ measures taken by Pakistan are more than $\mathrm{AD}$ measures taken against Pakistan. 
Table-6: Symmetry Ratios

\begin{tabular}{lcc}
\hline \multicolumn{3}{c}{ Symmetry Ratio: Antidumping } \\
\multicolumn{1}{c}{ 2000-2005 } \\
Country & Measure Symmetry & Initiation Symmetry \\
\hline Argentina & 19.9 & 9.4 \\
Australia & 6.7 & 6.3 \\
Chili & 0 & 0.3 \\
China & 0.34 & 0.4 \\
Egypt & 0 & 2.2 \\
EU & 5.5 & 6 \\
India & 5.5 & 3.3 \\
Pakistan & 1.2 & 0.98 \\
South Africa & 1.7 & 2 \\
Thailand & 0.55 & 0.5 \\
United States & 1.55 & 6 \\
\hline
\end{tabular}

For Pakistan, $\mathrm{AD}$ initiation taken and being investigated are almost the same, with a symmetry ratio of 0.98 . In this parameter besides India and Argentina, the USA also joins the race of severe investigators compared to being investigated.

\section{Trade Impact of Antidumping}

We developed a null hypothesis for total imports that the mean imports after $\mathrm{AD}$ is greater than or equal to the mean imports before $\mathrm{AD}$, which means there is an effect of $\mathrm{AD}$ duty on imports. Thus the null hypothesis is: The mean of imports after $\mathrm{AD}$ duty $>$ mean of imports before antidumping duty. 
Table-7: Statistical Results of Trade Impact

\begin{tabular}{lcccccc}
\hline Product & \multicolumn{2}{c}{ Total Import } & \multicolumn{2}{c}{$\begin{array}{c}\text { Named country } \\
\text { import }\end{array}$} & \multicolumn{2}{c}{$\begin{array}{c}\text { Non-named country } \\
\text { import }\end{array}$} \\
\hline & T value & Probability & T value & Probability & T value & probability \\
\hline Tinplate & -3.25 & 0.01129 & -3.36 & 0.0219 & 2.78 & 0.016 \\
Sorbitol & -0.674 & 0.25 & -5.1 & 0.00069 & 6.87 & 0.00012 \\
GAA & -4.55 & 0.003 & -7.125 & 0.00084 & -6.045 & 0.0002 \\
Acrylic & -1.9 & 0.0470 & -1.77 & 0.0681 & -3.48 & 0.0064 \\
PVC Resin & -1.45 & 0.099 & -1.43 & 0.066 & 1.423 & 0.102 \\
UFMC & -4.15 & 0.0016 & -4.52 & 0.0016 & 0.55 & 0.314 \\
\hline
\end{tabular}

While looking at Table-7, and on the basis of probability and $\mathrm{T}$ values, the null hypothesis for all the products (total import) is rejected, except one, i.e. Sorbitol, for which the probability value is highly insignificant. Our alternative hypothesis is that imports after antidumping duties are imposed are less than the imports before antidumping duties. We can conclude from the significant $T$ values and level of probability that trade of investigated products declined significantly in most cases after the imposition of $\mathrm{AD}$ duty.

$\mathrm{AD}$ duty reduces the import of the investigated product from the named country. Import from non-named countries sometimes occupies the market of named countries after the imposition of $\mathrm{AD}$ duty, which is called trade diversion. Therefore, the null hypothesis for non-named countries is the opposite of the null hypothesis for named countries i.e. the sample mean of imports before duty is greater than or equal to the sample mean after duty for non-named countries.

The value of probability in non-named countries shows that imports from non-named countries increased after the imposition of $\mathrm{AD}$ duty on the named countries. In two cases, i.e. PVC Resin and UFMC, imports from non-named countries do not increase significantly after the imposition of $\mathrm{AD}$ duty on named countries. This shows that trade in these two cases decreased rather than being diverted. The $\mathrm{T}$ test and probability value of named countries in Table 7 clearly show that in all cases trade was reduced significantly when $\mathrm{AD}$ duty was imposed. This result also verifies that $\mathrm{AD}$ duty imposition reduces trade and it is anti-competitive in nature. 


\section{Conclusion}

The results are consistent with vast body of literature on trade reduction and diversion after the imposition of $\mathrm{AD}$ duty. An economic rationale has been followed in half of the cases in imposing $\mathrm{AD}$ duty by Pakistan. Despite a small number of cases, Pakistan emerged as one of the most important $\mathrm{AD}$ users on the basis of $\mathrm{AD}$ use relative to total import share. Resultantly, intensive use of $\mathrm{AD}$ reduced trade and increased the trade barriers, which could lead to a reduction in economic gains, but fortunately, trade diversion reduces the chances of trade reduction in Pakistan. This suggests that $\mathrm{AD}$ measures simply reduced imports from targeted countries without any substantial effect. The key message that has emerged out of this research is that trade diversion persists in the case of Pakistan. In some cases, trade diversion is substantial and offsets the effect of $\mathrm{AD}$ measures on named countries to the benefit of non-named countries.

Evidence presented in this paper indicates that the political economy argument is the strongest one in explaining Pakistan's AD actions. AD actions protect the highly concentrated industries. In recent years, many observers have begun to note the proliferation of $\mathrm{AD}$ measures and the possibility that the established users of this trade policy instrument are being retaliated against. But retaliation (strategic trade policy) seems to play no role in the $\mathrm{AD}$ cases of Pakistan.

Results also demonstrate that the $\mathrm{AD}$ intensity of Pakistan is significantly high as compared to its share in world imports. Intensive $\mathrm{AD}$ use can be justified, if it follows an economic rationale, such as: antipredation, strategic trade policy and political economy arguments.

The most frequently offered justification for $\mathrm{AD}$ is the prevention of predation. Pakistan's AD enforcement has clearly not addressed predation issues. This result is the same as has been found for US AD cases (Shin 1998). The procedure which has been followed in this study for the predation test shows that the necessary conditions for predatory pricing exist, because firms have a large market share.

One can conclude that antidumping policies which are designed to ensure fair competition and improve economic efficiency may in fact reduce fair competition in the case of Pakistan. 
Appendix-A

The History of AD cases in Pakistan

\begin{tabular}{|c|c|c|c|c|c|c|}
\hline S.No & 1 & 2 & 3 & 4 & 5 & 6 \\
\hline H.S Code & 7210.1200 & $\begin{array}{l}2905.4400 \\
\& 3824.6000\end{array}$ & 2915.2100 & 5501.3000 & 3904.1000 & 3909.1010 \\
\hline Custom Duty & $25 \%$ & $25 \%$ & $25 \%$ & $20 \%$ & $25 \%$ & $25 \%$ \\
\hline Product & Tinplate & Sorbitol Oil & GAA & Acrylic Tow & PVC Resin & Urea \\
\hline $\begin{array}{l}\text { Name of } \\
\text { Applicant }\end{array}$ & $\begin{array}{l}\text { M/s Siddiq } \\
\text { Sons } \\
\text { Tinplate } \\
\text { (Pvt) Ltd. } \\
\text { Karachi }\end{array}$ & $\begin{array}{l}\text { M/s Habib } \\
\text { Arkady (Pvt) } \\
\text { Ltd, Karachi }\end{array}$ & $\begin{array}{l}\text { M/s Wah } \\
\text { Nobel } \\
\text { Acetates } \\
\text { Ltd }\end{array}$ & $\begin{array}{l}\text { M/s Dewan } \\
\text { Salman } \\
\text { Fibre Ltd }\end{array}$ & $\begin{array}{l}\text { Engro sahi } \\
\text { Ploymers } \\
\text { and } \\
\text { Chemicals } \\
\text { Ltd }\end{array}$ & $\begin{array}{l}\text { Dynea } \\
\text { Pakistan } \\
\text { Ltd }\end{array}$ \\
\hline $\begin{array}{l}\text { Date of } \\
\text { Initiation }\end{array}$ & $\begin{array}{l}26-02- \\
2002\end{array}$ & $06-03-2003$ & 03-09-2003 & $17-03-2004$ & $25-06-2004$ & $\begin{array}{l}12-01- \\
2005\end{array}$ \\
\hline Exporters & Mac Steel & $\begin{array}{l}\text {.Roquette } \\
\text { Freres, } \\
\text {.P.T Sorini } \\
\text { Corp }\end{array}$ & $\begin{array}{l}\text { Chan Chun } \\
\text { Petrro- } \\
\text { Chemical } \\
\text { Co. Ltd }\end{array}$ & $\begin{array}{l}\text { Pumice } \\
\text { Trading Co } \\
\text { East Sea } \\
\text { Sail Co. } \\
\text { Pouya } \\
\text { Tarabar } \\
\text { Naviy Azot }\end{array}$ & $\begin{array}{l}\text { LG Internat: } \\
\text { Corporation, } \\
\text { Iran Petro- } \\
\text { chemical }\end{array}$ & $\begin{array}{l}\text { Bluestar } \\
\text { Sinochem } \\
\text { Yixing }\end{array}$ \\
\hline $\begin{array}{l}\text { Origin of } \\
\text { Export }\end{array}$ & $\begin{array}{l}\text { South } \\
\text { Africa }\end{array}$ & $\begin{array}{l}\text { France } \\
\text { Indonesia }\end{array}$ & Taiwan & Uzbekistan & $\begin{array}{l}\text { South Korea } \\
\text { Iran }\end{array}$ & China \\
\hline $\begin{array}{l}\text { Dumping } \\
\text { Margin }\end{array}$ & $39.32 \%$ & $\begin{array}{l}96.50 \% \text { and } \\
22.26 \% \text { for } \\
\text { Franc and } \\
\text { Indonesia } \\
\text { respectively }\end{array}$ & $13.77 \%$ & $12.71 \%$ & $\begin{array}{l}40.18 \% \& \\
31.06 \% \text { for } \\
\text { Korea and } \\
\text { Iran } \\
\text { respective: }\end{array}$ & $10 \%$ \\
\hline $\begin{array}{l}\text { Imposition } \\
\text { Date of } \\
\text { Provisional } \\
\text { Duty }\end{array}$ & $\begin{array}{l}22-07- \\
2002\end{array}$ & $19-07-2003$ & 18-06-2004 & $10-12-2004$ & $24-02-2005$ & $\begin{array}{l}18-07- \\
2005\end{array}$ \\
\hline $\begin{array}{l}\text { Provisional } \\
\text { Duty at the } \\
\text { rate of }\end{array}$ & $23.91 \%$ & $\begin{array}{l}96.50 \% \text { on } \\
\text { France \& } \\
91.12 \% \text { on } \\
\text { Indonesia }\end{array}$ & $13.77 \%$ & $12.71 \%$ & $\begin{array}{l}40.18 \% \text { on } \\
\text { Korea and } \\
31.06 \% \text { on } \\
\text { Iran }\end{array}$ & $10 \%$ \\
\hline $\begin{array}{l}\text { Imposition } \\
\text { Date of } \\
\text { Definitive } \\
\text { duty }\end{array}$ & $\begin{array}{l}26-11- \\
2002\end{array}$ & $19-11-2003$ & 18-06-2004 & $10-12-2004$ & 24-02-2005 & $\begin{array}{l}18-07- \\
2005\end{array}$ \\
\hline $\begin{array}{l}\text { Definitive } \\
\text { Duty at the } \\
\text { rate of }\end{array}$ & $27.33 \%$ & $\begin{array}{l}96.50 \% \text { on } \\
\text { France } \\
22.3 \% \text { on } \\
\text { Indonesia }\end{array}$ & $13.77 \%$ & $12.71 \%$ & $\begin{array}{l}40.18 \% \text { on } \\
\text { Korea } \\
36.01 \% \text { on } \\
\text { Iran }\end{array}$ & $10 \%$ \\
\hline
\end{tabular}




\section{References}

Aggarwal, Aradhna, 2002, "Antidumping Law and Practice: An Indian Perspective”, CRIER Working Paper No. 85, New Delhi.

Barcelo, J., 1971, "Antidumping Laws as Barriers to Trade-the US and International Dumping Code”, 57 Come11 L R, pp. 491-560.

Blonigen, Bruce A. and Prusa, Thomas J., 2003, "Antidumping and Retaliation Threats”, Journal of International Economics, Vo1. 60, pp. 249-273.

Boltuck, R. D., 1991, "Assessing the Effects on the Domestic Industry of Price Dumping”, in P. K. M. Tharakan (ed), Policy implication of Antidumping Measures (North Holland).

Bourgeoise, J and P. Messerline, 1998, “The European Community's Experience”, in Robert Z. Lawrence (ed.), Brookings Trade forum 1998 (Washington, DC: Brookings institution).

Brenton, P., 2001, 'Anti-Dumping Policies in the EU and Trade Diversion', European Journal of Political Economy, Vo1. 17, 593-607.

Deardorff, A. V., 1993, "Economic Perspective in Antidumping Law", Ann Arbor, Mich: University of Michigan Press.

Finger, J. M, H. K. Hall, and D. R. Nelson, 1982, "The Political Economy of Administered Protection”, American Economic Review, Vol. 72(3), 452-466.

Finger, J. M., 1993, “Antidumping: How it Works and Who Gets Hurt" (Ann Arbor, MI: University of Michigan Press).

Finger, J. M., Francis Ng and Sonam, Wangchuk, 2000, "Antidumping and Safeguard Policy Presented at the University of Michigan , Gerald R.Ford School of Public Policy and Japan Economy Program Conference, Oct, 5-6, 2000.

Hansen, W. L. and T. J. Prusa, 1996, "Cumulation and ITC Decision Making: The Sum of the Parts is Greater Than the Whole", Economic Inquiry, Vol. 34(4), pp. 746-769. 
Hansen, W. L. and T. J. Prusa, 1997, "The Economics and Politics of Trade Policy: An Empirical Analysis of ITC Antidumping Decisions”, Review of International Economics, Vol. 5(2), 230-245.

Hansen, W. L. and Thomas J. Prusa, 1995, "The Road Most Taken: The Rise of Title VII Protection”, The World Economy, Vol. 18(2), pp.295-313.

Hutton, S and Trebilcock M., 1990, "An Empirical Study of the Application of Canadian Anti-dumping Laws: A Search for Normative Rationales”, Journal of World Trade, Vol. 123(4).

Katrak Homi, 1977, "Multinational Monopolies and Commercial Policies", Oxford Economic Papers, Vol.29, pp.283-91.

Leclerc, J., 1999, "Reforming Antidumping Law: Balancing and Interests of Consumers and Domestic Industries”, Mc Gill Law Journal, Vol. 44, pp. 113-119.

Lee, H. K. and J. S. Mah, 2003, "Institutional Changes and Antidumping Decisions in The United States", Journal of Policy Modeling, Vol. 25 , pp. 555-565.

Messerlin P. A. and P. K. M. Tharakan, 1999, "The Question of Contingent Protection”, World Economy, Vo1. 22(9), pp. 1251-1270.

Messerlin, P. A., 1989, “The EC Antidumping Regulations: A First Economic Appraisal 1980-1985, Weltwirtschaftliches Archive, Vol. 138(3), pp. 563-587.

Miranda, J; Raul, A. Torres and Mario. Ruiz, 1998, "The International Use of Antidumping: 1987-1997", Journal of World Trade, Vo1. 32, pp. $5-72$.

Prusa, T. J. and S. Skeath, 2002, "The Economic and Strategic Motives for Antidumping Filing", Weltwirtschaftliches Archive, Vol. 138(3), pp. 389-413.

Prusa, Thomas J., 1997, "The Trade Effects of US Antidumping Actions", in Robert C. Feenstra (Ed), The Effects of US Trade Protection and Promotion Policies. Chicago: University of Chicago Press, 191-213.

Sevedberg Peter, 1979, "Optimal Tariff Policy on Imports from Multinationals”, Economic Record, Vol. 55, pp.64-67. 
Shin, J. H., 1998, "Possible instances of Predatory Pricing in recent US Antidumping Cases”, in Robert Z. Lawrence (ed.), Brookings Trade Forum 1998 (Washington, DC: Brookings Institution).

Staiger, Robert W. and Frank A. Wolak, 1994, "Measuring Industry Specific Protection: Antidumping in the United States", Brooking Papers on Economics Activity: Microeconomics, pp. 51-118.

Stiglitz, J. E., 1997, "Dumping on Free Trade: The U.S. Import trade Laws", Southern Economic Journal, Vol. 64(2), pp. 402-424.

Tharakan P.K. Mathew, 1994, "Anti-dumping policy and practice of the European Union: an overview", Economisch en sociaal tijdschrift, Vol. 48(4), pp. 557-575.

Tharakan, P .K. M and J. Waelbroeck, 1994, "Antidumping and Countervailing Duty Decisions in the E.C. and in the US: An Experiment in Comparative Political Economy", European Economic Review, Vol. 38(1), pp.171-193.

Tharakan, P. K. M, David Greenaway, and J. Tharakan, 1998, "Cumulation and Injury Determination of the European Community in Antidumping Cases”, Weltwirtschaftliches Archiv, Vol. 134(2), 320-39.

Tharakan, P. K. M., 1995, "Political Economy and Contingent Protection", The Economic Journal, Vo1. 105, pp. 1550-1564.

Trebilcock M.J. and J. Quinn, 1979 "The Canadian Antidumping Act: A Reaction to Professor Slayton”, Canadian-US Law Journal, Vol. 2.

Tyson, L.D. (1992), “who's Bashing Wom?, Institute for International Economics, US Journal Account Office, 1990a, pp.3.

Viner, Jacob, 1923, "Dumping: A Problem in International Trade", Chicago, IL: University of Chicago Press.

Willig, D. R., 1998, "Economic Effects of Antidumping Policy", in Robert Z. Lawrence (ed.), Brookings Trade Forum 1998 (Washington, DC: Brookings Institution). 